\title{
WYBRANE NOWE DETERMINANTY OTYŁOŚCI
}

\author{
SELECTED NEW DETERMINANTS OF OBESITY
}

Anna Wiśniewska, Barbara Ślusarska, Grzegorz Nowicki, Bernadeta Jędrzejkiewicz

Zakład Medycyny Rodzinnej i Pielęgniarstwa Środowiskowego, Wydział Nauk o Zdrowiu, Uniwersytet Medyczny w Lublinie

DOI: https://doi.org/10.20883/ppnoz.2019.22

\section{STRESZCZENIE}

Wstęp. Wysiłki zmierzające do ograniczenia otyłości przez dietę, ćwiczenia, edukację czy zastosowanie nielicznych leków nie są w stanie, jak dotąd, skutecznie i długofalowo rozwiązać problemu. Jednak stanowią podstawę współczesnych działań w tym obszarze.

Cel. Celem pracy był przegląd piśmiennictwa i jego analiza pod kątem wybranych czynników związanych z otyłością u osób dorosłych. Przedstawiono związek między otyłością a czynnikami genetycznymi, zespołem metabolicznym, witaminą D oraz afaminą. Zastosowano metodę analizy piśmiennictwa. Przeglądu literatury dokonano na podstawie danych zawartych w bazie GBL, PubMed, Google Scholar oraz informacji dostępnych na stronach internetowych. Wyniki. Wiedza o nosicielstwie polimorfizmów i mutacji genów predysponujących do otyłości, wiedza na temat suplementacji witaminy D oraz wiedza na temat nowych badań biochemicznych w otyłości mogą przyczynić się do skuteczniejszego zapobiegania i leczenia otyłości oraz związanych z nią chorób. W zapobieganiu powstawania zespołu metabolicznego i jego powikłań podstawowe znaczenie nieustannie ma zmiana stylu życia z modyfikacją diety, zwiększeniem aktywności fizycznej i redukcją masy ciała.

Wnioski. Otyłość jest narastającym problemem wysoko rozwiniętych społeczeństw. Poszukiwane są więc nowe sposoby walki z tym problemem, a także nowe sposoby zapobiegania groźnym powikłaniom, jak zespół metaboliczny, cukrzyca typu II czy choroby układu krążenia.

Słowa kluczowe: otyłość, zespół metaboliczny, czynniki genetyczne, witamina D, afamina.

\section{ABSTRACT}

Introduction. Efforts to reduce obesity through diet, exercise, education or the use of few drugs, so far, have not been able to solve the problem effectively and to a long-term extent. However, they constitute the basis of contemporary activities in this area.

Aim. The aim of the study was to review and analyse the literature in terms of selected factors related to obesity in adults. The relationship between obesity and genetic factors, metabolic syndrome, vitamin $\mathrm{D}$ and afamine was presented. The literature review method was used. The literature was overviewed on the grounds of data contained in the GBL database, PubMed, Google Scholar and information available on websites.

Results. The knowledge of the carrier state of polymorphisms and gene mutations predisposing to obesity, knowledge of vitamin D supplementation and knowledge of new biochemical research on obesity can contribute to more effective prevention and treatment of obesity and the related diseases. In preventing the formation of metabolic syndrome and its complications, the vital and recurring factors are a lifestyle change and diet modification, increase in physical activity and weight reduction.

Conclusions. Obesity is a growing problem in highly developed societies. Therefore, new ways to combat the problem, as well as new ways to prevent dangerous complications such as metabolic syndrome, type II diabetes mellitus or cardiovascular diseases are being explored.

Keywords: obesity, metabolic syndrome, genetic factors, vitamin D, afamine.

\section{Wstęp}

Otyłość jest to przewlekłe zaburzenie metabolizmu spowodowane głównie nadmierną podążą pokarmu w stosunku do zapotrzebowania energetycznego organizmu. Prawie wszystkie przypadki otyłości wynikają z połączenia uwarunkowań genetycznych oraz przewlekłego zaburzenia równowagi pomiędzy nadmiarem energii pochodzącym z pożywienia, a także zużyciem tej energii $w$ procesach przemiany materii oraz zużyciem jej podczas aktywności fizycznej [1].

W ostatnich latach coraz większym problemem epidemiologicznym staje się otyłość, wciąż przez społeczeństwo niepostrzegana $w$ kategoriach choroby. Według danych Głównego Urzędu Statystycznego (GUS) z 2015 roku ponad 50\% Polaków po 15. roku życia ma nadwagę lub jest otyła [2]. Badania wykazały, że otyłość jest ważnym czynnikiem ryzyka cukrzycy, chorób układu krążenia, nowotworów i w konsekwencji przedwczesnej śmierci. Wysiłki zmierzające do ograniczenia otyłości przez dietę, ćwiczenia, edukację czy zastosowanie nielicznych leków nie są w stanie, jak dotąd, skutecznie i długofalowo rozwiązać problemu [3].

\section{Cel pracy}

Celem pracy jest analiza wybranych czynników związanych z otyłością u osób dorosłych. Przedstawiono związek między otyłością a czynnikami genetycznymi, zespołem metabolicznym, witaminą D oraz afaminą. Zastosowano 
metodę niesystematycznej analizy piśmiennictwa. Przeglądu literatury dokonano na podstawie danych zawartych w bazie GBL, PubMed, Google Scholar oraz informacji dostępnych na stronach internetowych.

\section{Wybrane uwarunkowania otyłości- Otyłość a czynniki genetyczne}

Etiologia otyłości jest złożona i wieloczynnikowa, wpływają na nią uwarunkowania genetyczne i czynniki środowiskowe obejmujące niską aktywność fizyczną oraz brak prawidłowo ukształtowanych postaw zdrowotnych. Wykazano, że u ludzi masa ciała matki koreluje z masą ciała potomstwa [3]. Badania kliniczne i epidemiologiczne wskazują, że u podstaw interakcji między środowiskiem, a genami leżą mechanizmy epigenetyczne. Nosicielstwo niektórych alleli sprzyja pewnemu zwiększonemu ryzyku zachorowania, choć nie jest to czynnik decydujący, gdyż dominującą rolę odgrywają jednak czynniki środowiskowe. Wiedza o nosicielstwie polimorfizmów i mutacji genów predysponujących do otyłości może przyczynić się do skuteczniejszego zapobiegania i leczenia otyłości oraz związanych z nią chorób.

Wśród czynników wpływających na masę ciała i rozmieszczenie tkanki tłuszczowej znaczącą rolę odgrywa wiele genów, a wśród nich szczególnie następujące:

- Gen FTO (ang. Fat mass obesity associatedgene) ma wpływ na proces pobierania pokarmu, preferencje $w$ stosunku do pokarmu oraz homostazę energetyczną, co wiąże się z regulacją akumulacji tłuszczów w organizmie i regulacje masy ciała. Badanie brytyjskie z udziałem prawie $3800 \mathrm{pa}$ cjentów z cukrzycą typu II (prawie 5,5 tys. osób w grupie kontrolnej) potwierdziło związek między polimorfizmem pojedynczego nukleotydu (SNP) genu FTO, znajdującego się na chromosomie 16, z występowaniem cukrzycy typu II. Jednocześnie stwierdzono, iż ten związek jest ściśle zależny od wskaźnika BMI [4]. Nosicielstwo allelu A genu FTO u noworodków (2 tygodnie po urodzeniu) wiązało się również $z$ wyższą brzuszną masą tłuszczową (prawie o 17\%). Związek allelu A ze znacznie wyższym BMI i masą tkanki tłuszczowej został potwierdzony również $w$ badaniu szkockim z udziałem 2700 dzieci w wieku 4-10 lat, gdzie grupa badana charakteryzowała się wyższą o 1,78 kg zawartością tkanki tłuszczowej niż w grupie kontrolnej [5].

- Gen leptyny (LEP, leptin), receptora leptyny (LEPR, leptin receptor) oraz receptora melanokortyny typu 4 (MC4R, melanocortin 4 receptor) - LEP I
MC mają podstawowe znaczenie w podwzgórzowej regulacji apetytu [6].

- Gen receptora aktywowanego proliferatoramiperoksysomów typu $\gamma$ (PPAR $\gamma$, peroxisomalproliferatoractivated receptor gamma) - receptor jest obecny w tkance tłuszczowej, jelicie grubym, nerce i mięśniach szkieletowych, odpowiada za różnicowanie fibroblastów w kierunku adipocytów oraz wpływa na metabolizm dojrzałych lipidów [7].

- Gen receptora $\beta_{3}$ adrenergicznego (ADRB3, beta-3 adrenergic receptor) - receptory biorą udział zarówno w procesach termogenezy, jak i lipolizy $w$ tkance tłuszczowej. Są to geny potencjalnie związane z predyspozycją do otyłości i chorób z nią związanych [8].

- Gen receptora endokannabinoidowego (CNR1, cannabinoid receptor) - receptory $\mathrm{CB}_{1}$ znajdujące się w mózgu są integralną częścią sieci kontrolującej apetyt [9].

\section{Otyłość a zespół metaboliczny}

Otyłość androidalna i jej konsekwencje metaboliczne, takie jak: insulinooporność, hiperinsulinemia, upośledzona tolerancja glukozy, dyslipidemia oraz nadciśnienie tętnicze są określane mianem zespołu metabolicznego [10].

Tkanka tłuszczowa nie tylko jest dla organizmu magazynem energetycznym, ale również wykazuje ważne działanie endokrynne. Adipocyty, komórki tkanki tłuszczowej oraz makrofagi obecne w tej tkance produkuja tzw. adipokiny, do których należą m.in. leptyna, adiponektyna, rezystyna, wisfatyna, omentyna, adipsyna, waspina. U osób otyłych obserwuje się podwyższone stężenia leptyny i rezystyny, a obniżone - adiponektyny. Niskie stężenia adiponektyny nie chronią tych osób przed niekorzystnym działaniem dla układu sercowo-naczyniowego cząstek adhezyjnych: VICAM 1, ICAM 1, selektyny E. Z kolei rezystyna wykazuje działanie przeciwstawne do adiponektyny - zwiększa insulinooporiność [11].

Tkanka tłuszczowa w zależności od lokalizacji wykazuje znaczące różnice w metabolicznej homeostazie. Trzewna tkanka tłuszczowa jest metabolicznie bardziej aktywna od tkanki tłuszczowej podskórnej. Nagromadzenie znacznej objętości tkanki tłuszczowej trzewnej jest przyczyną rozwoju przewlekłego stanu zapalnego. Stan zapalny w otyłości to przewlekła odpowiedź zapalna zainicjowana przez nadmiar składników odżywczych w adipocytach prowadząca do podwyższonego poziomu markerów zapalnych, takich jak CRP, haptoglobina, IL-1, IL-6, MCP-1 (białko chemotaktyczne monocytów-1), PAl-1 i TNF- $\alpha$. W otyłości następuje napływ makrofagów do tkanki tłusz- 
czowej, a ich ilość jest proporcjonalna do stopnia nadwagi. Co więcej, aktywność makrofagów obecnych w tkance tłuszczowej osób otyłych różni się od funkcjonowania makrofagów u osób szczupłych. U osób szczupłych makrofagi są zaangażowane $\mathrm{w}$ procesy naprawcze tkanek i przeciwdziałanie rozwojowi stanu zapalnego; u osób otyłych odpowiadają one za nasilenie stanu zapalnego, produkując cytokiny prozapalne [12, 13].

W zapobieganiu powstawania zespołu metabolicznego i jego powikłań podstawowe znaczenie ma zmiana stylu życia z modyfikacją diety, zwiększeniem aktywności fizycznej i redukcją masy ciała. Kelly i wsp. [11] wykazali, że systematyczny wysiłek fizyczny (aerobik), kontynuowany przez 8 tygodni w badanej grupie młodocianych z nadwagą spowodował poprawę funkcji środbłonka naczyń oraz spadkową tendencję stężenia insuliny.

Badania występowania zespołu metabolicznego przeprowadzone przez NHANES od 2003 do 2012 roku w Stanach Zjednoczonych wykazały, że prawie 35\% wszystkich dorosłych i 50\% osób w wieku 60 lat i więcej mieli zespół metaboliczny. Badania te sugerują, że częstość występowania zespołu metabolicznego u osób dorosłych pozostaje stabilna od 2007 roku i spadła u kobiet. Większa świadomość zespołu metabolicznego i jego konsekwencje przyczyniły się po poprawy w optymalizacji leczenia czynników ryzyka, takich jak nadciśnienie i cukrzyca. Ponadto dane te nie podważają podejmowania dalszych kroków w celu zwalczania choroby i profilaktyki [14].

\section{Otyłość a witamina D}

Otyłości często towarzyszą ogólnoustrojowe niedobory witaminy $D$, definiowane jako stężenie kalcyfediolu [25(OH) D] w surowicy krwi $<30 \mathrm{ng} / \mathrm{ml}$. Kalcytriol ma strukturę zbliżoną do hormonów steroidowych i wykazuje działanie hormonopodobne. Działa on na komórki docelowe poprzez receptor jądrowy VDR (ang. vitamin D receptor). Przełomowym okazało się odkrycie, że receptor ten nie jest obecny wyłącznie w komórkach kostnych, kanalików nerkowych, nabłonka jelit, ale także w większości komórek ludzkiego organizmu: w sercu, ścianie naczyń krwionośnych, mózgu, gruczole krokowym, gruczole sutkowym, nadnerczach, komórkach $\beta$ trzustki, jelicie cienkim, jelicie grubym, przytarczycach, limfocytach, makrofagach, keratynocytach i komórkach nowotworowych [15]. Receptory witaminy D zajmują 2776 miejsc genomowych i modelują ekspresję 229 genów w obrębie tkanek, w związku z czym zaopatrzenie w witaminę D wydaje się mieć potencjalny wpływ na liczne procesy fizjologiczne [16]. Synteza witaminy D w skórze jest warunkowana wieloma czynnikami zewnętrznymi jak: szerokość geograficz- na, pora roku, warunki atmosferyczne, sposób ubierania się, stosowanie kremów z filtrem UV, które mogą ograniczać działanie promieni słonecznych na skórę, tym samym zmniejszać wytwarzanie witaminy $D$ [17]. Witamina $D$ jest także dostarczana z dietą, choć istnieje niewiele jej źródeł: masło, mleko sojowe, ryby (makrela, tuńczyk, sardynki, dziki łosoś) i niektóre grzyby (kurki) [18]. Średnio z dietą w krajach europejskich dostarczane 2,5-4,0 $\mu \mathrm{g}$ witaminy D/dobę, co stanowi zaledwie 3-5\% dziennego zapotrzebowania. Wymienione wyżej czynniki powodują, iż niedobór witaminy D staje się coraz bardziej powszechny.

Wśród przyczyn niedoboru podkreśla się niewystarczającą syntezę skórną spowodowaną unikaniem, z różnych przyczyn, promieniowania słonecznego. $Z$ drugiej strony stwierdzono, że u osób otyłych ekspozycja na tę samą dawkę promieniowania UVB powoduje około $50 \%$ niższy wzrost stężenia 25(OH)D w surowicy w porównaniu z osobami z prawidłową masą ciała [19]. Mimo że otyłość skutkuje większą powierzchnią ciała, a zatem można oczekiwać, że zwiększy ona skórną syntezę witaminy $D$. Badania również wykazują powiązanie między masą ciała, tkanką tłuszczową, a opalaniem u osób powyżej 65 roku życia. Odkrycie to można wytłumaczyć znanym spadkiem zdolności syntetycznej witaminy $D$ w skórze związanej z wiekiem [20]. Kolejną ważną przyczyną niedoboru witaminy D u otyłych jest powstawanie ogólnoustrojowego stanu zapalnego, który związany jest z nieprawidłową produkcją cytokin i aktywacją sygnałów prozapalnych poprzez nadmiar tkanki tłuszczowej trzewnej. Tkanka tłuszczowa ogrywa rolę w regulacji homeostazy organizmu, włączając w to mechanizmy odpornościowe. Cheng i wsp. [21] wykazali, że im wyższa zawartość tkanki tłuszczowej w organizmie, tym większy deficyt witaminy $D$, ponadto ujemna korelacja pomiędzy stężeniem 25(OH)D i zawartością tkanki tłuszczowej jest większa w przypadku otyłości brzusznej. Badanie koreańskie z udziałem 1660 dzieci również potwierdziło związek między niedoborem witaminy D, a otyłością, otyłością brzuszną, hipertriglicerydemią i zespołem metabolicznym [22]. Badania wykazały, że u osób otyłych występuje znacznie niższe stężenie $25(\mathrm{OH})$ D niż u osób o prawidłowej masie ciała, a po zastosowaniu odpowiedniej suplementacji witaminy D wartość stężenia 25(OH)D znacząco się podniosła [23]. Co ciekawe, wzbogacenie diety w witaminę $D$ prowadzi do wzrostu stężenia 25(OH)D w osoczu i zmniejszenia otyłości brzusznej [24] Kolejne polskie badania na grupie 2687 badanych potwierdziło czynniki ryzyka deficytu witaminy $D$, obejmujące płeć męską, młodszy wiek, wyższą masę ciała i wyższą wartość BMI. W tej grupie obecność deficytu ujawniło $75 \%$ ankietowanych, wyrażonego stężeniem $25(\mathrm{OH})<20 \mathrm{ng} / \mathrm{ml}$ [25]. 
Szereg badań wskazuje na związek pomiędzy stężeniem witaminy $\mathrm{D} w$ ustroju, a metabolizmem tkanki tłuszczowej [26, 11]. Stwierdzono obecność receptorów witaminy D na komórkach beta trzustki, adipocytach oraz komórkach mięśni szkieletowych. Witamina D poprzez receptory VDR może ograniczać oporność na insulinę i zwiększać wychwyt glukozy w tkance mięśniowej [27]. Wielu badaczy sugeruje związek witaminy $D$ z cukrzycą typu 1 i 2. Badania polimorfizmu genu receptora VDR wskazują na związek z cukrzycą typu 1, insulinoopornością oraz wydzielaniem insuliny. Udowodniono, że suplementacja witaminy D obniża 8-krotnie ryzyko wystąpienia zachorowania na cukrzycę typu I u dzieci. U osób z niedoborem witaminy $D$ jest większe ryzyko wystąpienia zespołu metabolicznego i insulinooporności $[28,29]$.

\section{Związek otyłości z afaminą}

Najnowsze wyniki badań ukazują istotny związek aktywności afaminy w osób z nadwagą i otyłością. Afamina jest określana jako ludzka witamina E w osoczu, wiążąca glikoproteiny, które są przetwarzane w wątrobie i wydzielane do krwi. Ponadto afamina również występuję w płynach ustrojowych, takich jak płyn mózgowo-rdzeniowy, pęcherzyki jajnika i płynach nasiennych. Funkcjonuje dodatkowo w tkankach mózgu, nerek, jądra i jajnika. Zbadano związek afaminy z lipoproteinami w osoczu, dzięki któremu stwierdzono, że więcej niż 97\% witaminy E była związana z lipoproteiną, co potwierdza, że witamina $E$ jest prawie całkowicie transportowana za pomocą lipoprotein w surowicy. Obserwowany transport witaminy E przez system lipoprotein jest również widoczny w płynach ustrojowych. Afamina istotnie koreluje z witaminą E w pęcherzyku jajnika i płynie mózgowo-rdzeniowym. Glikoproteina badana w surowicy pacjentów z różnymi chorobami, wykazała silny związek z białkiem C-reaktywnym. Badania te ujawniły nowy pogląd afaminy $w$ relacji z białkiem c-reaktywnym, co powinno zachęcić do dalszych badań. Jedną z metod badań afaminy w osoczu jest test ELISA, dzięki któremu możemy badać interesujące nas elementy, funkcje, właściwość białka [30].

\section{Podsumowanie}

Otyłośćjestnarastającym problemem wysoko rozwiniętych społeczeństw. Poszukiwane są więc nowe czynniki warunkujące i sposoby walki, a także nowe metody zapobiegania groźnym powikłaniom, jak zespół metaboliczny, cukrzyca typu II czy choroby układu krążenia. Ostatnie lata przyniosły wiele nowych informacji o funkcjonowaniu tkanki tłuszczowej i zaburzeniach jej metabolizmu, leżących u podłoża rozwoju otyłości i jej powikłań. Wśród szeregu mechanizmów rozpatrywanych $w$ aspekcie patogenezy otyłości znajduje się stan zapalny, obserwowany w obrębie nadmiernie rozwiniętej tkanki tłuszczowej, a także znaczenie czynników genetycznych oraz roli witaminy D [13]. Należy mieć nadzieję, że przyszłe badania nad określeniem czynników genetycznych, na których opiera się dziedziczenie ryzyka otyłości, przyczynią się do poszerzenia wiedzy i wyznaczą nowe kierunki skutecznych interwencji terapeutycznych u ludzi [6].

\section{Oświadczenia}

Oświadczenie dotyczące konfliktu interesów

Autorzy deklarują brak konfliktu interesów.

\section{Źródła finansowania}

Autorzy deklarują brak źródeł finansowania.

\section{Piśmiennictwo}

1. Drąg J, Goździalska A, Gawędzka A, Jaśkiewicz J. Nowe wskaźniki w patomechanizmie rozwoju otyłości - elongazy i desaturazy nienasyconych kwasów tłuszczowych. W: Grażyna Dębska, Jerzy Jaśkiewicz (red)., Interdyscyplinarne aspekty nauk o zdrowiu. Krakowskie Towarzystwo Edukacyjne sp. z o.o. - Oficyna Wydawnicza AFM, Kraków 2010 33-40.

2. Wełnicki M, Śliż D, Filipiak KJ, Siebert J, Naruszewicz M, Mamcarz A. Forum Med Rodz. 2016; 10(4): 179-188.

3. Pokrywka M, Kieć-Wilk B, Polus A, Wybrańska I. Metylacja DNA a otyłość prosta. Postepy Hig Med. Dosw; 2014, 68 1383-1391.

4. Frayling T, Timpson $\mathrm{N}$, Weedon $\mathrm{M}$ et al. A common variant in the FTO gene is associated with body mass in- dex andpredisposes to childhood and adult obesity. Science. 2007; 316 889-894.

5. Cecil J, Tavendale R, Watt P et al. An obesity associated FTO gene variant and increased energy intake in children. $\mathrm{N}$ Engl J Med. 2008; 359: 2558-2566

6. Majorczyk M, Baran M, Jaworek J. Rola witaminy D w rozwoju i przebiegu otyłości. Pielęg Pol. 2016, 1(59): 91-97.

7. Hojka A, Rapak A. Receptory aktywowane proliferatoram peroksysomów (PPAR). Właściwości antyproliferacyjne. Postepy Hig Med. Dosw. 2011; 65: 404-413.

8. Stosio M, Witkowicz A, Kowalska A, Karabon L. Genetyczne uwarunkowania zaburzonej ekspresji termogeniny (UCP1) w otyłości prowadzącej do zespołu metabolicznego. Postepy Hig Med Dosw. 2016; 70: 1389-1403

9. Kolackov K, Łaczmański Ł, Bednarek tupikowska G. Wpływ polimorfizmów genu FTO na ryzyko ōtyłości. EOiZPM. 2010; 6(2): 101-107.

10. Dołowacka A. Zespół metaboliczny jako kolejna choroba cy wilizacyjna. Piel Zdr Publ. 2016; 6(3): 241-245.

11. Jung A. Otyłość - choroba cywilizacyjna. Pediatr Med. Rodz $2014 ; 10(3)$ : 226-232.

12. Gordon S, Martinez FO. Alternative activation of macrophages mechanism and functions. Immunity 2010, 32(5): 593-604.

13. Nuszkiewicz J, Kwiatkowska A, Majko K, Wesołowski R, Szewczyk-Golec K. Stres oksydacyjny i stan zapalny a rozwój otyłości: protekcyjne działanie melatoniny. Probl Hig Epidemiol 2017; 98(3): 226-232.

14. Aguilar M, Bhuket T, Torres S, I wspł. Prevalence of the Metabolic Syndrome in the United States, 2003-2012.JAMA. 2015; 313(19): 1973-1974. 
15. Zdrojewicz Z, Chruszczewska E, Miner M. Wpływ witaminy D na organizm człowieka. Med Rodz. 2015; 2: 61-66.

16. Ramagopalan S, Heger A, Berlanga A, [et al.]. A ChP-seq defined genome-wide map of vitamin $\mathrm{D}$ receptor binding: associations with disease and evolution. Gen Res. 2010, 20, 1352-1360.

17. Brzozowska M, Karowicz-Bilińska A. Rola niedoboru witaminy D w patofizjologii zaburzeń występujących w zespole policystycznych jajników. Ginekol Pol. 2013; 83: 456-460.

18. Respondek M, Pudło H. Znaczenie witaminy D w występowaniu wybranych schorzeń. Journal of Education, Health and Sport. 2016; 6(9): 653-663.

19. Nair R, Maseeh A. Vitamin D. The „sunshine" vitamin. J Pharmacol Pharmacother. 2012; 3(2): 118-126.

20. Vanlint S. Vitamin D and Obesity Nutrients. 2013, 5: 949-956.

21. Cheng S, Massaro JM, Fox CS et al. Adiposity, cardiometabolic risk, and vitamin D status: the Framingham Heart Study. Diabetes2010; 59: 242-248.

22. Lee SH, Kim SM, Park HS et al. Serum 25-hydroxyvitamin Dlevels, obesity and the metabolic syndrome among Korean children. Nutr Metab Cardiovasc Dis. 2013; 23 (8): 785-791.

23. Saliba W, Barnett-Griness O, Rennert G. The relationship between obesity and the increase in serum $25(\mathrm{OH}) \mathrm{D}$ levels in response to vitamin $\mathrm{D}$ supplementation. Osteoporos Int. 2013; 24 (4): 1447-1454.

24. Caron-Jobin M, Morisset AS, Tremblay A et al. Elevated serum $25(\mathrm{OH})$ D concentrations, vitamin $\mathrm{D}$, and calcium intakes are associated with reduced adipocyte size in women. Obesity (Silver Spring). 2011; 19: 1335-1341.

25. Płudowski P, Konstantynowicz J, Jaworski M, Abramowicz $P$ Ducki C. Ocena stanu zaopatrzenia w witaminę D w popu- lacji osób dorosłych w Polsce. Stand Med, Pediatr. 2014; 11 609-617.

26. Roth CL, Elfers C, Kratz M et al. Vitamin D deficiency in obese children and its relationship to insulin resistance and adipokines. J Obes 2011; 2011: 495101.

27. Żukowska-Szczechowska E, Kiszka B. Niedobór witaminy D - rozpoznawanie i postępowanie w celu redukcji ryzyka sercowo-naczyniowego u chorych na cukrzycę. Via Medica, Gdańsk 2011

28. Antczak M, Głąbiński A. Aktualne poglądy na temat roli witaminy $\mathrm{D}$ w patogenezie stwardnienia rozsianego. Aktualn Neurol 2013; 13(1): 24-30.

29. Gadomski A. Skutki niedoboru witaminy D w organizmie człowieka. Nowa Pediatr. 2017; 1: 34-37.

30. Dieplinger H, Dieplinger B. Afamin - A pleiotropic glycoprotein involved in various disease states. Clinica Chimica Acta 446. 2015: 105-110.

Zaakceptowano do edycji: 20.08.19

Zaakceptowano do publikacji: 26.09.19

Adres do korespondencji:

Anna Wiśniewska

ul. Grochowskiego 13/95

05-500 Piaseczno

tel. +48728703090

e-mail: aniasykut@wp.pl 